\title{
Association of S100B polymorphisms and serum S100B with risk of systemic lupus erythematous in a Chinese population
}

\author{
Yulan $\mathrm{Lu}^{1 *}$, Huatuo Huang ${ }^{1 *}$, Chunhong Liu ${ }^{1 *}$, Yonglong Zeng ${ }^{1}$, Rong Wang ${ }^{1}$, Chunfang Wang ${ }^{1}$, Yesheng \\ Wei ${ }^{1}$ (D) and Yan Lan $^{2}$ \\ ${ }^{1}$ Department of Clinical Laboratory, Affiliated Hospital of Youjiang Medical University for Nationalities, \\ No.18 Zhongshan Road II, Baise 533000, Guangxi, China. \\ ${ }^{2}$ Department of Dermatology, Affiliated Hospital of Youjiang Medical University for Nationalities, Guangxi, \\ China.
}

\begin{abstract}
The aim of this study was to investigate whether the S100B polymorphisms are associated with systemic lupus erythematous (SLE) in a Chinese population. A total of 313 SLE patients and 396 control subjects were enrolled in the present study. The genotypes of three SNPs (rs9722, rs881827 and rs1051169) in S100B gene were detected by single base extension polymerase chain reaction (SBE-PCR). Serum S100B levels were determined by enzyme-linked immunosorbent assay (ELISA). Rs 1051169 was associated with an increased risk of SLE (C vs. G: adjusted $\mathrm{OR}=1.46,95 \% \mathrm{Cl}, 1.18-1.80, p=0.001$; $\mathrm{CC}$ vs. GG: adjusted $\mathrm{OR}=1.99,95 \% \mathrm{Cl}, 1.32-3.02, p=0.001 ; \mathrm{CC}+\mathrm{GC}$ vs. GG: adjusted $\mathrm{OR}=1.54,95 \% \mathrm{Cl}, 1.13-2.11, p=0.007$; $\mathrm{CC}$ vs. $\mathrm{GC}+\mathrm{GG}$ : adjusted $\mathrm{OR}=1.67,95 \% \mathrm{Cl}, 1.16-2.42$, $p=0.006$ ). Haplotype analysis showed that the $\mathrm{G}-\mathrm{G}-\mathrm{C}$ haplotype was associated with an increased risk of SLE $(\mathrm{OR}=1.50,95 \% \mathrm{Cl}, 1.14-1.98, p=0.004)$. Stratified analyses showed that the $\mathrm{rs} 1051169$ polymorphism was associated with an increased risk of neurologic disorder in SLE patients (C vs. G: OR=1.78, 95\% Cl, 1.22-2.59, $p=0.003$; GC vs. GG: $\mathrm{OR}=2.33,95 \% \mathrm{Cl}, 1.14-4.77, \mathrm{P}=0.019$; $\mathrm{CC}$ vs. $\mathrm{GG}$ : $\mathrm{OR}=3.02,95 \% \mathrm{Cl}, 1.39-6.53, p=0.004 ; \mathrm{CC}+\mathrm{GC}$ vs. GG: OR=2.57, 95\% $\mathrm{Cl}=1.31-5.04, p=0.005)$. In addition, SLE patients with neurologic disorder carrying the rs $1051169 \mathrm{GC} / \mathrm{CC}$ genotypes present a higher serum S100B levels compared with that carrying the GG genotype ( $p$ $<0.05$ ). Our results indicate that the rs 1051169 polymorphism may be involved in the pathogenesis of SLE.
\end{abstract}

Keywords: S100B, polymorphisms, serum levels, SLE, neurologic disorder.

Received: November 17, 2017; Accepted: July 18, 2018.

\section{Introduction}

Systemic lupus erythematous (SLE) is a common systemic autoimmune disease characterized by autoantibody production and immune complex deposition, resulting in damage to multiple tissues and organs, as well as physiological function impairment (Aringer, et al., 2016). Most of the SLE patients will develop various symptoms, such as malar rash, arthritis, nephritis, and neurologic disorders (Wada, et al., 2017). In China, the prevalence of SLE is $0.03 \%$ and it has come to be a heavy burden on family and society (Li, et al., 2012; Holloway, et al., 2014). It represents a primary challenge to health care and is considered as a major Chinese health concern. Yet to date, the exact pathogenic mechanism of SLE has not been fully elucidated. Several risk factors have been identified to contrib-

Send correspondence to Yesheng Wei. Department of Clinical Laboratory, Affiliated Hospital of Youjiang Medical University for Nationalities, No.18 Zhongshan Road II, Baise 533000, Guangxi, China. E-mail: yeshengwei88@163.com

* These authors equally contributed to this work. ute to the pathogenesis of SLE, such as genetic, environmental, infection, and hormonal factors. Among the wellknown predisposing factors, genetic factors seem to play a key role in the susceptibility (Alarcon-Segovia, et al., 2005; Tiffin, et al., 2013; Ulff-Moller, et al., 2017).

As is known, many cytokines are involved in the pathogenesis of autoimmune diseases. S100B is a member of the S100 family and primarily secreted by astrocytes, but to a lesser extent it is also produced by other cell types, such as dendritic cell, macrophages, monocytes, and T cells (Donato, et al., 2009, 2013; Miki, et al., 2013). S100B is thought to have intracellular and extracellular roles in the regulation of many diverse processes, such as cell growth and motility, cell-cycle regulation, transcription, differentiation, and $\mathrm{Ca}^{2+}$ homeostasis (Yardan, et al., 2011). In addition, S100B has been viewed as a damage-associated molecular pattern (DAMP) involved in the inflammatory response, and serves as a generic receptor for the advanced glycation end products (RAGE) activator in the context of the inflammatory response (Xiao, et al., 2014; Uspenskaya, 
et al., 2015; Cao, et al., 2017). Increasing evidence has shown that $\mathrm{S} 100 \mathrm{~B}$ binding to RAGE can promote the release of inflammatory cytokines via the activation of NF$\kappa \mathrm{B}, \mathrm{JNK}, \mathrm{PI} 3 \mathrm{~K}$, and P38 MAPK (Bianchi, et al., 2010, 2011). These signaling pathways were known to be involved in the regulation of SLE (Zhi-Chun, et al., 2012; Shi, et al., 2015). In addition, substantial evidence has showed that $\mathrm{S} 100 \mathrm{~B}$ is associated with pathological injury or clinical severity in a variety of autoimmune disease (Wang, et al., 2013; Gomez-Tourino, et al., 2015; Lapa, et al., 2017). Within this context, we hypothesized that S100B might be involved in the development of SLE.

The gene encoding S100B is located on chromosome 21q22.2-q22.3 and consists of three exons and two introns. Recently, genetic association studies have indicated that S100B polymorphisms are related to human diseases, such as invasive aspergillosis, autism spectrum disorder, bipolar affectivedisorder, and dyslexia (Roche, et al., 2007; Egger, et al., 2014; Matsson, et al., 2015; Dix, et al., 2016). In addition, genetic variants in the S100B gene have been reported as significantly associated with the higher expression of S100B (Liu, et al., 2005; Hohoff, et al., 2010). Given the important roles that the abnormal expression of S100B plays in the development of autoimmune and inflammatory diseases (Hofmann, et al., 1999; Hwang, et al., 2011; Bechmann, et al., 2013; Gomez-Tourino, et al., 2015), we hypothesized that SNPs in the S100B gene may influence the expression of S100B and ultimately be involved in the etiology of SLE. To test this hypothesis, we selected three SNPs (rs9722, rs881827 and rs1051169) in the S100B gene and performed a case-control study to investigate the association of these SNPs with susceptibility to SLE in a Chinese population.

\section{Material and Methods}

\section{Subjects}

A total of 313 SLE patients (63 men and 250 women, average age $38.05 \pm 12.93$ years) were recruited from the Department of Dermatology, Affiliated Hospital of Youjiang Medical University for Nationalities, Guangxi, China between January 2013 and September 2016. The diagnosis of SLE was based on the 1997 revised American College of Rheumatology (ACR) SLE criteria (Hochberg, 1997). Their medical records were reviewed with particular attention to neuropsychiatric manifestations, which were ascertained by relevant specialists, employing laboratory and imaging investigations and were objectively documented. The 396 controls (98 men and 298 women, average age $39.48 \pm 12.10$ years) were matched to the patients on the basis of age and gender, and they were recruited from Health Medical Center of the hospital during the same period. According to the thorough clinical and laboratory evaluation, none of them was found to have any history of autoimmune disorders. Data about demographic and clinical features were collected from hospital records or by questionnaire, and were reviewed by experienced physicians. Written informed consent was obtained from all participants, and this study was approved by the research ethics committee of our hospital.

\section{DNA extraction}

Blood samples from all subjects were collected in EDTA-containing tubes. Genomic DNA was isolated from peripheral blood mononuclear cells using a DNA extraction kit (QIAGEN, China) according to the manufacturer's instructions and then stored at $-70^{\circ} \mathrm{C}$ for later use.

\section{Determination of S100B genotype}

Primer probes were designed using Primer Express Software (version 3.0) and synthesized by Applied Biosystems (Foster City, CA). The primers used were as follows: rs9722: ACAACACGGCTGGAAAGCTCAG (forward), GATGGAGACG GCGAATGTGACT (reverse), TTTTTTTTTTTTTTTTTTGCCAAACCTTTCCTGTAA CAGAGA (extended); rs881827: TGTGTGTGGAAGTC CCTGTCTCA (forward), CCCTGCACTGTGGTTGTTC CTC (reverse), TTTTTTTTTTTTTTTTTTTTTTTTTTT TGTTGCTGAAGTAACTCTTGGGAAC(extended); rs1051169: TCACCTTCA GGGCAGCTGAGAA (forward), TGGAAGGGAGGGAGACAAGCAC(reverse), TTTTTTTTTTTTTTTTTTTTTTTTTTTTTTTTTTTTTT TCACAAGCTGAAGAAATCCGAACT(extended). SNP genotyping was performed by SBE-PCR. Amplifications were performed in a total volume of $20 \mu \mathrm{L}$, comprised of $3.0 \mathrm{mmol} / \mathrm{L} \mathrm{Mg}^{2+}, 0.3 \mathrm{mmol} / \mathrm{L}$ dNTP, $1 \mathrm{U}$ HotStarTaq polymerase, $1 \mu \mathrm{L}$ genomic DNA, $1 \mu \mathrm{L}$ PCR primer and $1 \mathrm{x}$ GC-I buffer (Takara, Japan). The PCR conditions included an initial denaturation step at $94^{\circ} \mathrm{C}$ for $20 \mathrm{~s}$, followed by 35 cycles with $20 \mathrm{~s}$ of denaturation at $94{ }^{\circ} \mathrm{C}, 30 \mathrm{~s}$ of annealing at $59^{\circ} \mathrm{Cm}$ and $1.5 \mathrm{~min}$ of elongation at $72^{\circ} \mathrm{C}$, followed by a final elongation step of $72^{\circ} \mathrm{C}$ for $2 \mathrm{~min}$. PCR products were digested with shrimp enzyme (Promega, Madison, WI) and excision enzyme (Epicentre, Madison WI). An ABI PRISM 3730XL analyzer (Applied Biosystems) was used to sequence the PCR products, and GeneMapper4.1 was used to analyze the sequencing data. The samples were reanalyzed and verified by DNA sequencing when conflicting results occurred. In addition, approximately $10 \%$ of all samples were randomly selected to be confirmed by DNA sequencing, and the results were $100 \%$ consistent.

\section{Serum S100B determination}

Serum samples from SLE patients and controls were separated from peripheral venous blood at room temperature and stored at $-70^{\circ} \mathrm{C}$ until use. The quantity determination of serum S100B were performed by ELISA kits (No: RD192090100R, BioVendor-Laboratorní medicína) following the manufacturer's protocol. The concentration of serum S100B was determined using a standard curve con- 
structed with the kit's standards over the range of 10-320 $\mathrm{pg} / \mathrm{mL}$.

\section{Statistical analysis}

All data were analyzed by the SPSS software version 17.0 (SPSS, Inc, Chicago, IL, USA). Hardy-Weinberg equilibrium (HWE) was tested by the chi-square test. Demographic and clinical data between groups were compared by chi-square test or Student's $t$-test. Logistic regression was used to estimate odds ratio (OR) and 95\% confidence interval $(95 \% \mathrm{CI})$. False discovery rate (FDR) approach was used to correct for multiple testing. In brief, the stringent $p$-value was considered statistically significant if it was less than 0.05 . The haplotype analysis was performed by online SHEsis software (Shi and He, 2005), and $p<0.05$ was considered to be statistically significant.

\section{Results}

\section{Clinical characteristics of the study participants}

A total of 313 SLE patients and 396 control subjects were included in this study. The clinical characteristics of the study participants are listed in Table 1 . There were no significant differences in age and gender distribution between the case and control groups $(p>0.05)$.

\section{Association of S100B polymorphisms with SLE risk}

The distributions of the S100B gene rs9722, rs881827 and rs1051169 in SLE patients and controls are shown in Table 2. The genotype distribution of the three

Table 1 - Clinical characteristics of the subjects.

\begin{tabular}{lccc}
\hline Characteristics & $\begin{array}{c}\text { SLE patients } \\
(\mathrm{n}=313)\end{array}$ & $\begin{array}{c}\text { Controls } \\
(\mathrm{n}=396)\end{array}$ & $p$-value \\
\hline Age, year (mean \pm SD) & $38.05 \pm 12.93$ & $39.48 \pm 12.10$ & 0.131 \\
Gender (M/F) & $63 / 250$ & $98 / 298$ & 0.145 \\
Cutaneous vasculitis (\%) & $146(46.65)$ & - & - \\
Family history of SLE (\%) & $89(28.43)$ & - & - \\
Arthritis (\%) & $139(44.41)$ & - & - \\
Pleuritis (\%) & $42(13.42)$ & - & - \\
Malar rash (\%) & $93(29.71)$ & - & - \\
Renal disorder (\%) & $161(51.44)$ & - & - \\
Neurologic disorder (\%) & $71(22.68)$ & - & - \\
Anti-dsDNA anti- & $153(48.88)$ & - & - \\
body-positive (\%) & & & - \\
Anti-Sm-positive (\%) & $123(39.30)$ & - & - \\
Anti-RNP-positive (\%) & $135(43.13)$ & - & - \\
ANA positive (\%) & $286(91.37)$ & & - \\
Low levels of C3 (\%) & $127(40.57)$ & - & - \\
Low levels of C4 (\%) & $101(32.27)$ & - & -
\end{tabular}

SLE, systemic lupus erythematosus; Anti-dsDNA, double-stranded DNA antibody; Anti-Sm, smith antibody; Anti-RNP, ribonucleoprotein antibody; ANA, antinuclear antibody; $\mathrm{C} 3$, complement 3; C4, complement 4 .
SNPs in the control group was in agreement with HWE (both $p>0.05$ ). The minor C allele of rs 1051169 , relative to the major $\mathrm{G}$ allele, appeared to have a significantly increased risk of SLE (C vs. G: adjusted OR $=1.46,95 \%$ CI, $1.18-1.80, p=0.001)$. Similarly, a statistical significance was also found for the rs1051169 CC genotype, dominant and recessive model (CC vs. GG: adjusted $\mathrm{OR}=1.99,95 \%$ $\mathrm{CI}, 1.32-3.02, \quad p=0.001 ; \mathrm{CC}+\mathrm{GC}$ vs. GG: adjusted $\mathrm{OR}=1.54,95 \% \mathrm{CI}, 1.13-2.11, p=0.007 ; \mathrm{CC}$ vs. $\mathrm{GC}+\mathrm{GG}$ : adjusted $\mathrm{OR}=1.67,95 \% \mathrm{CI}, 1.16-2.42, p=0.006)$. The $p$ values remained significant after correction for multiple testing. However, no significant association between other SNPs (rs9722 and rs881827) and SLE risk was observed ( $p$ $>0.05$ ).

\section{Analysis of haplotype distribution between SLE patients and controls}

The haplotypes frequencies of the three SNPs in S100B gene among the cases and controls were also estimated in our study. It was performed online using the SHEsis software, and the possible eight haplotypes are listed in Table 3. G-G-G and G-G-C were the two major haplotypes, accounting for $27.7 \%$ and $20.3 \%$, and $30.2 \%$ and $14.5 \%$ in both SLE patients and controls, respectively. Moreover, we found the G-G-C haplotype to be associated with an increased risk of SLE compared with controls $(\mathrm{OR}=1.50,95 \% \mathrm{CI}, 1.14-1.98, p=0.004)$.

\section{Association of rs 1051169 polymorphisms with clinical features}

We further performed a stratification analysis by comparing the distribution of genotype and allele frequencies in rs 1051169 between positive and negative patients in 13 specific clinical features. Significant differences were observed between the rs 1051169 polymorphism and neurologic disorder ( $p=0.013, p=0.003$, respectively) (Table 4). In addition, patients in the case group were further divided into two groups, which were the neurologic disorder (ND) group and non-neurologic disorder (NND) group. When we further estimated the rs 1051169 polymorphism and the risk of neurologic disorder, we found the rs1051169 C allele, GC genotype, $\mathrm{CC}$ genotype and dominant model to be associated with increased susceptibility to neurologic disorder in SLE patients (C vs. G: OR=1.78, 95\% CI, 1.22-2.59, $p=0.003$; $\mathrm{GC}$ vs. $\mathrm{GG}: \mathrm{OR}=2.33,95 \% \mathrm{CI}, 1.14-4.77$, $p=0.019$; $\mathrm{CC}$ vs. $\mathrm{GG}: \mathrm{OR}=3.02,95 \% \mathrm{CI}, 1.39-6.53$, $p=0.004 ; \mathrm{CC}+\mathrm{GC}$ vs. $\mathrm{GG}: \mathrm{OR}=2.57,95 \% \mathrm{CI}=1.31-5.04$, $p=0.005)$ (Table 5).

\section{Association between S100B polymorphisms and serum S100B levels}

We also investigated the association between S100B polymorphisms and serum S100B levels. We found that the serum S100B levels in SLE patients with neurologic disorder were significantly higher than in non-neurologic 
Table 2 - Association between S100B polymorphisms and risk of SLE.

\begin{tabular}{|c|c|c|c|c|c|}
\hline SNPs & Controls $(\mathrm{n}=396)$ & $\operatorname{SLE}(n=313)$ & Adjusted OR $(95 \% \mathrm{CI})^{*}$ & $P^{*}$ & $P_{B H}$ \\
\hline \multicolumn{6}{|l|}{ rs9722 } \\
\hline GG & $182(46.0)$ & $154(49.2)$ & $1.0(\operatorname{Ref})$ & - & \\
\hline GA & $170(42.9)$ & $134(42.8)$ & $0.93(0.68-1.27)$ & 0.646 & 0.745 \\
\hline AA & $44(11.1)$ & $25(8.0)$ & $0.68(0.40-1.16)$ & 0.160 & 0.394 \\
\hline G & $534(67.4)$ & $442(70.6)$ & 1.0 (Ref) & - & \\
\hline A & $258(32.6)$ & $184(29.4)$ & $0.87(0.69-1.09)$ & 0.211 & 0.396 \\
\hline Dominant (AA+GA vs. GG) & & & $0.88(0.65-1.18)$ & 0.394 & 0.537 \\
\hline Recessive (AA vs. GA+GG) & & & $0.70(0.42-1.18)$ & 0.184 & 0.394 \\
\hline \multicolumn{6}{|l|}{ rs881827 } \\
\hline GG & $157(39.6)$ & $127(40.5)$ & $1.0(\operatorname{Ref})$ & - & \\
\hline GA & $171(43.2)$ & $142(45.4)$ & $1.04(0.75-1.44)$ & 0.813 & 0.871 \\
\hline AA & $68(17.2)$ & $44(14.1)$ & $0.82(0.53-1.29)$ & 0.389 & 0.537 \\
\hline G & $485(61.2)$ & $396(63.3)$ & 1.0 (Ref) & - & \\
\hline A & $307(38.8)$ & $230(36.7)$ & $0.93(0.75-1.16)$ & 0.517 & 0.646 \\
\hline Dominant (AA+GA vs. GG) & & & $0.98(0.72-1.33)$ & 0.888 & 0.888 \\
\hline Recessive (AA vs. GA+GG) & & & $0.81(0.53-1.22)$ & 0.303 & 0.505 \\
\hline \multicolumn{6}{|l|}{ rs1051169 } \\
\hline GG & $158(39.9)$ & $95(30.4)$ & 1.0 (Ref) & - & \\
\hline $\mathrm{GC}$ & $170(42.9)$ & $139(44.4)$ & $1.37(0.97-1.92)$ & 0.072 & 0.216 \\
\hline $\mathrm{CC}$ & $68(17.2)$ & $79(25.2)$ & $1.99(1.32-3.02)$ & 0.001 & $0.015^{*}$ \\
\hline G & $486(61.4)$ & $329(52.6)$ & 1.0 (Ref) & - & \\
\hline $\mathrm{C}$ & $306(38.6)$ & $297(47.4)$ & $1.46(1.18-1.80)$ & 0.001 & $0.015^{*}$ \\
\hline Dominant (CC+GC vs. GG) & & & $1.54(1.13-2.11)$ & 0.007 & $0.026^{*}$ \\
\hline Recessive (CC vs. GC+GG) & & & $1.67(1.16-2.42)$ & 0.006 & $0.026^{*}$ \\
\hline
\end{tabular}

Boldface indicates significantly different. Ref: reference; OR: odds ratio; $95 \%$ CI: $95 \%$ confidence interval. *: adjusted by age and gender. $P_{\mathrm{BH}}: P$ values corrected by Benjamin-Hochberg $(\mathrm{B}-\mathrm{H})$ method. $P_{\mathrm{BH}}{ }^{*}$ remains significant after FDR test is applied.

Table 3 - Haplotype distribution in the patients with SLE and the controls.

\begin{tabular}{lcccc}
\hline Haplotype & $\begin{array}{c}\text { Controls } \\
(2 \mathrm{n}=792)\end{array}$ & $\begin{array}{c}\text { SLE patients } \\
(2 \mathrm{n}=626)\end{array}$ & $\begin{array}{c}\text { OR } \\
(95 \% \mathrm{CI})\end{array}$ & $p$ \\
\hline A A C & $57(7.2)$ & $49(7.9)$ & $1.11(0.75-1.65)$ & 0.608 \\
A A G & $71(8.9)$ & $39(6.2)$ & $0.68(0.45-1.02)$ & 0.060 \\
A G C & $72(9.1)$ & $63(10.0)$ & $1.12(0.78-1.59)$ & 0.545 \\
A G G & $59(7.4)$ & $33(5.2)$ & $0.69(0.44-1.07)$ & 0.098 \\
G A C & $62(7.8)$ & $57(9.2)$ & $1.19(0.82-1.73)$ & 0.370 \\
G A G & $117(14.8)$ & $84(13.4)$ & $0.89(0.66-1.21)$ & 0.457 \\
G G C & $115(14.5)$ & $127(20.3)$ & $\mathbf{1 . 5 0 ( 1 . 1 4 - 1 . 9 8 )}$ & $\mathbf{0 . 0 0 4}$ \\
G G G & $239(30.2)$ & $173(27.7)$ & $0.88(0.70-1.11)$ & 0.291 \\
\hline
\end{tabular}

Boldface indicates significantly different. OR: odds ratio; 95\% CI: 95\% confidence interval.

disorder patients and controls $(p<0.05$, respectively) (Figure 1A). Considering that the rs 1051169 polymorphism may play an important role in the etiology of SLE, especially in the patients with neurologic disorder, we then performed a comparison between rs1051169 genotypes and serum S100B levels, and observed that the patients with neurologic disorder carrying the rs $1051169 \mathrm{CC} / \mathrm{GC}$ genotypes presented higher serum S100B levels compared with those carrying the rs $1051169 \mathrm{GG}$ genotype (both $p<0.05$ ) (Figure 1B).

\section{Discussion}

In this study, we investigated the association between three SNPs in the S100B gene and SLE risk in a Chinese population. We found that the rs $1051169 \mathrm{C}$ allele, $\mathrm{CC}$ genotype, dominant model ( $\mathrm{CC}+\mathrm{GC}$ vs. $\mathrm{GG})$ and recessive model $(\mathrm{CC}$ vs. $\mathrm{GC}+\mathrm{GG})$ were significantly associated with increased risk of SLE. Haplotype analysis showed that the G-G-C haplotype was associated with an increased risk of SLE. Moreover, further stratified analyses showed that SLE patients carrying the rs $1051169 \mathrm{C}$ allele, GC genotype, $\mathrm{CC}$ genotype and dominant model (CC+GC vs. $\mathrm{GG})$ were more likely to develop neurologic disorder. In addition, we observed that in individuals carrying rs1051169 $\mathrm{CC}$ genotype there was an association with abnormal expression of S100B in SLE patients with neurologic disorder. Taken together, these findings indicate that the S100B 
Table 4 - Association analysis of rs1051169 polymorphism with clinical features.

\begin{tabular}{|c|c|c|c|c|c|c|c|c|}
\hline \multirow[t]{2}{*}{ Variables } & \multirow[t]{2}{*}{$+/-$} & \multicolumn{3}{|c|}{ Genotypes } & \multirow[t]{2}{*}{$p$} & \multicolumn{2}{|c|}{ Allele } & \multirow[t]{2}{*}{$p$} \\
\hline & & GG & CG & $\mathrm{CC}$ & & G & $\mathrm{C}$ & \\
\hline \multirow[t]{2}{*}{ Cutaneous vasculitis } & + & $52(31.7)$ & $75(45.7)$ & $37(22.6)$ & 0.516 & $179(54.6)$ & $149(45.4)$ & 0.289 \\
\hline & - & $43(28.9)$ & $64(43.0)$ & $42(28.2)$ & & $150(50.3)$ & $148(49.7)$ & \\
\hline \multirow[t]{2}{*}{ Family history of SLE } & + & $25(28.1)$ & $36(40.4)$ & $28(31.5)$ & 0.279 & $86(48.3)$ & $92(51.7)$ & 0.180 \\
\hline & - & $70(31.3)$ & $103(46.0)$ & $51(22.7)$ & & $243(54.2)$ & $205(45.8)$ & \\
\hline \multirow[t]{2}{*}{ Arthritis } & + & $47(33.8)$ & $62(44.6)$ & $30(21.6)$ & 0.314 & $156(56.1)$ & $122(43.9)$ & 0.111 \\
\hline & - & $48(27.6)$ & $77(44.2)$ & $49(28.2)$ & & $173(49.7)$ & $175(50.3)$ & \\
\hline \multirow[t]{2}{*}{ Pleuritis } & + & $15(35.7)$ & $20(47.6)$ & $7(16.7)$ & 0.371 & $50(59.5)$ & $34(40.5)$ & 0.169 \\
\hline & - & $80(29.5)$ & $119(43.9)$ & $72(26.6)$ & & $279(51.5)$ & $263(48.5)$ & \\
\hline \multirow[t]{2}{*}{ Malar rash } & + & $31(33.3)$ & $42(45.2)$ & $20(21.5)$ & 0.567 & $104(55.9)$ & $82(44.1)$ & 0.274 \\
\hline & - & $64(29.1)$ & $97(44.1)$ & $59(26.8)$ & & $225(51.1)$ & $215(48.9)$ & \\
\hline \multirow[t]{2}{*}{ Renal disorder } & + & $48(29.8)$ & $78(48.4)$ & $35(21.7)$ & 0.239 & $174(54.0)$ & $148(46.0)$ & 0.445 \\
\hline & - & $47(30.9)$ & $61(40.1)$ & 44 (28.9) & & $155(51.0)$ & $149(49.0)$ & \\
\hline \multirow[t]{2}{*}{ Neurologic disorder } & + & $12(16.9)$ & $35(49.3)$ & $24(33.8)$ & 0.013 & $59(41.5)$ & $83(58.5)$ & 0.003 \\
\hline & - & $83(34.3)$ & $104(43.0)$ & $55(22.7)$ & & $270(55.8)$ & $214(44.2)$ & \\
\hline \multirow[t]{2}{*}{ Anti-dsDNA } & + & $50(32.7)$ & $61(39.9)$ & $42(27.5)$ & 0.286 & $161(52.6)$ & $145(47.4)$ & 0.977 \\
\hline & - & $45(28.1)$ & $78(48.8)$ & $37(23.1)$ & & $168(52.5)$ & $152(47.5)$ & \\
\hline \multirow[t]{2}{*}{ Anti-Sm } & + & $30(24.4)$ & $62(50.4)$ & $31(25.2)$ & 0.134 & $122(49.6)$ & $124(50.4)$ & 0.232 \\
\hline & - & $65(34.2)$ & $77(40.5)$ & $48(25.3)$ & & $207(54.5)$ & $173(45.5)$ & \\
\hline \multirow[t]{2}{*}{ Anti-RNP } & + & $46(34.1)$ & $62(45.9)$ & $27(20.0)$ & 0.331 & $154(57.0)$ & $116(43.0)$ & 0.142 \\
\hline & - & $52(29.2)$ & $78(43.8)$ & $48(27.0)$ & & $182(51.1)$ & $174(48.9)$ & \\
\hline \multirow[t]{2}{*}{ ANA } & + & $88(30.8)$ & $130(45.5)$ & $68(23.8)$ & 0.148 & $306(53.5)$ & $266(46.5)$ & 0.125 \\
\hline & - & $7(25.9)$ & $9(33.3)$ & $11(40.7)$ & & $23(42.6)$ & $31(57.4)$ & \\
\hline \multirow[t]{2}{*}{ Low levels of $\mathrm{C} 3$} & + & $36(28.3)$ & $65(51.2)$ & $26(20.5)$ & 0.110 & $137(53.9)$ & $117(46.1)$ & 0.567 \\
\hline & - & $59(31.7)$ & $74(39.8)$ & $53(28.5)$ & & $192(51.6)$ & $180(48.4)$ & \\
\hline \multirow[t]{2}{*}{ Low levels of $\mathrm{C} 4$} & + & $27(26.7)$ & $53(52.5)$ & $21(20.8)$ & 0.136 & $107(53.0)$ & $95(47.0)$ & 0.886 \\
\hline & - & $68(32.1)$ & $86(40.6)$ & $58(27.4)$ & & $222(52.4)$ & $202(47.6)$ & \\
\hline
\end{tabular}

Boldface indicates significantly different. +: positive; -: negative.

Table 5 - Association of rs 1051169 polymorphism with neurologic disorder risk.

\begin{tabular}{lccccc}
\hline Group & & $+(\mathrm{n}=71)$ & $-(\mathrm{n}=242)$ & OR $(95 \% \mathrm{CI})$ & $p$-value \\
\hline Genotype & $\mathrm{GG}$ & $12(16.9)$ & $83(34.3)$ & $1.0(\mathrm{Ref})$ & - \\
& $\mathrm{GC}$ & $35(49.3)$ & $104(43.0)$ & $\mathbf{2 . 3 3}$ & $\mathbf{0 . 0 1 9}$ \\
& & & & $\mathbf{( 1 . 1 4 - 4 . 7 7 )}$ & \\
& $\mathrm{CC}$ & $24(33.8)$ & $55(22.7)$ & $\mathbf{3 . 0 2}$ & $\mathbf{0 . 0 0 4}$ \\
Allele & $\mathrm{G}$ & $59(41.5)$ & $270(55.8)$ & $1.0(\mathrm{Ref})$ & - \\
& $\mathrm{C}$ & $83(58.5)$ & $214(44.2)$ & $\mathbf{1 . 7 8}$ & $\mathbf{0 . 0 0 3}$ \\
& & & & $\mathbf{( 1 . 2 2 - 2 . 5 9 )}$ & \\
Dominant & $\mathrm{GG}$ & $12(16.9)$ & $83(34.3)$ & $1.0(\mathrm{Ref})$ & - \\
& $\mathrm{GC}+\mathrm{CC}$ & $59(83.1)$ & $159(65.7)$ & $\mathbf{2 . 5 7}$ & $\mathbf{0 . 0 0 5}$ \\
& & & & $\mathbf{( 1 . 3 1 - 5 . 0 4 )}$ & \\
Recessive & $\mathrm{CC}$ & $24(33.8)$ & $55(22.7)$ & $1.0(\mathrm{Ref})$ & - \\
& $\mathrm{GG}+\mathrm{GC}$ & $47(66.2)$ & $187(77.3)$ & 1.74 & 0.059 \\
& & & & $(0.98-3.09)$ & \\
\hline
\end{tabular}

Boldface indicates significantly different. OR: odds ratio. 95\% CI: 95\% confidence interval. +: positive; -: negative. gene rs1051169 polymorphism may play a critical role in the etiology of SLE, especially in patients with neurologic disorder.

The synonymous variant SNP rs 1051169 is located in the promoter region of the S100B gene, and several studies have reported an association between the rs 1051169 polymorphism and human diseases, however, the results were inconsistent. Zhai et al. (2011) found that the rs 1051169 variant was correlated with schizophrenia patients' poorer spatial ability in a Chinese population. Similarly, a casecontrol study conducted by Liu et al. (2005) reported that the rs1051169 GG genotype was associated with an increased risk of schizophrenia in a Chinese population. However, Guo et al. (2013) have tried to detect an association of the rs 1051169 polymorphism with Parkinson's disease in a Chinese population, but failed to obtain a positive result. In this study, our findings were in agreement with the positive results of Zhai et al. (2011) and Liu et al. (2005), as we found that the rs $1051169 \mathrm{C}$ allele, CC genotype, $\mathrm{CC}+\mathrm{GC}$ vs. GG and $\mathrm{CC}$ vs. $\mathrm{GC}+\mathrm{GG}$ had 1.46-fold, 

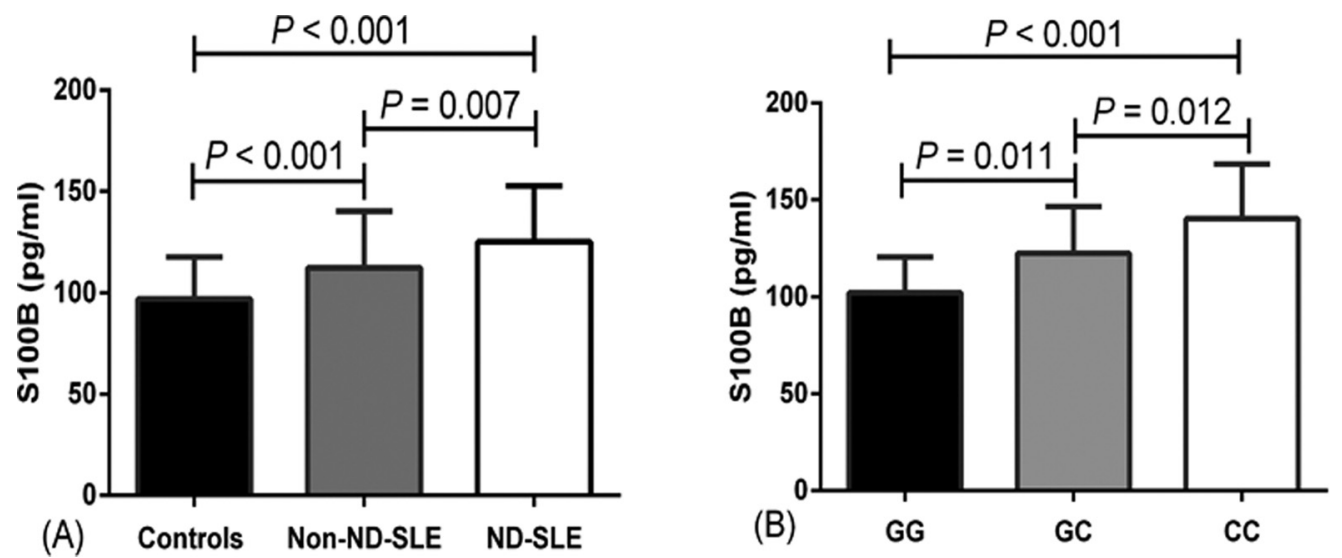

Figure 1 - ELISA detection of S100B levels (A) The SLE patients with neurologic disorder (125.08 $\pm 20.34 \mathrm{pg} / \mathrm{mL}, \mathrm{n}=71)$ showed higher serum S100B levels than non-neurologic disorder patients $(112.30 \pm 27.98 \mathrm{pg} / \mathrm{mL}, \mathrm{n}=71)$ and controls $(97.16 \pm 20.34 \mathrm{pg} / \mathrm{mL}, \mathrm{n}=71)$, respectively [both $p<0.05]$. (ND-neurologic disorder). (B) The SLE patients with neurologic disorder carrying the rs1051169 CC genotype (140.29 $\pm 28.17 \mathrm{pg} / \mathrm{mL}, \mathrm{n}=24)$ showed significantly higher serum S100B levels than whose with GC $(122.47 \pm 24.11 \mathrm{pg} / \mathrm{mL}, \mathrm{n}=35)$ and GG genotype $(102.24 \pm 18.26 \mathrm{pg} / \mathrm{mL}, \mathrm{n}=12)$, respectively (both $p<0.05$ ).

1.99-fold, 1.54-fold and 1.67-fold increased risks of developing SLE, respectively. Furthermore, a stratified analysis showed that the rs $1051169 \mathrm{C}$ allele, GC genotype, CC genotype, and $\mathrm{CC}$ vs. $\mathrm{GC}+\mathrm{GG}$ were associated with increased susceptibility to neurologic disorder in SLE patients. In addition, the SLE patients with neurologic disorder carrying $\mathrm{CC}$ or CG genotypes seem to exhibit relatively higher levels of expression S100B compared with those carrying the GG genotype. It is known that polymorphisms in the promoter region of certain genes might regulate their expression by altering the binding sites of transcription factors (Sun, et al., 2007; Shao, et al., 2017). We hypothesized that the synonymous SNP rs1051169 located in the exon of S100B may exert an influence on splicing, thereby affecting the levels of serum S100B, which ultimately potentiate S100B-mediated pro-inflammatory processes, increase SLE risk, and promote neurologic disorder development.

With regard to rs 9722 and disease risk, contradictory results were also observed. Matsson et al. (2015) reported that the rs9722 $\mathrm{T}$ allele was associated with dyslexia in a German family. In a case-control study, Li et al. (2017) demonstrated that the rs $9722 \mathrm{~T}$ allele was significantly associated with the risk of severehand, foot, and mouth disease. A positive result was also observed in schizophrenia patients (Zhai, et al., 2011). However, Yang K et al. (2008) showed that the rs 9722 polymorphism was not correlated with the risk of major depressive disorder in a Chinese population. Our results are in concordance with the negative result of Yang K et al. (2008). Several possibilities need to be taken into account to explain the negative results. Firstly, genetic polymorphisms play different roles in different diseases, especially in diverse ethnicities. Furthermore, we cannot rule out the possibility that the negative result is due to the relatively small number of subjects. Regarding the rs881827 polymorphism, up to now, a very limited number of studies has assessed the association of rs881827 poly- morphism with human disease susceptibility. In our study, no association of rs881827 SNP with SLE risk was observed.

SLE is a complex chronic inflammatory disease. Although the exact mechanisms responsible for initiating SLE remain unclear, it is well known that inflammatory cytokines play an important and diverse role in the pathogenesis of SLE. S100B is a multigene family of small (-10 $\mathrm{kDa}) \mathrm{Ca}^{2+}$ binding proteins, which can combine with RAGE to induce the secretion of a variety of thepro-inflammatory cytokines, such as TNF- $\alpha$, IL- $1 \beta$, IL- 6 , and IL-8 (Bianchi, et al., 2010; Dang, et al., 2014; Niven, et al., 2015). Several studies have demonstrated that these inflammatory cytokines play crucial roles in the pathogenic process of SLE (Sun, et al., 2000; Ye, et al., 2014). Besides, previous study showed that serum TNF- $\alpha$, IL- $1 \beta$, IL- 6 , and IL-8 levels in central nervous system neuropsychiatric SLE (CNS-NPSLE) cases were higher than those in the control and non-CNS SLE groups (Wang, et al., 2015). Moreover, higher serum S100B levels have been reported to reflect brain injury and increased permeability of the blood-brain barrier (BBB) (Yang XY et al., 2008; Fragoso-Loyo, et al., 2010). In our study, we observed that serum S100B levels in SLE patients with neurologic disorder were significantly higher than in non-neurologic disorder patients and controls. Based on this background, the positive results in our study were biologically reasonable.

Although the current study showed that S100B polymorphisms may play a critical role in the etiology of SLE, our study also has the following limitations. Firstly, the relatively small sample size may have limited the statistical power in our study. Secondly, all participants were recruited from the same hospital, so the possibility of selection bias cannot be ruled out. Thirdly, due to the lack of complete clinical data we cannot assess the impact of medi- 
cal regimens on the results of this study. Another limitation is that data on environmental exposure is not available, which prevented further analysis of the effect of a gene-environment interaction on SLE risk. Therefore, further studies with larger sample sizes and including gene-environment interaction are warranted.

\section{Conclusions}

Our results indicate that the S100B gene rs 1051169 polymorphism may play a major role in the pathogenesis and development of SLE. Further studies with larger samples and in different populations are needed to confirm these findings.

\section{Acknowledgments}

This work was supported by the National Natural Science Foundation of China (No. 81560552; No. 81260234) and the Innovation project of Guangxi Graduate Education (NO. YCSW2017213).

\section{Conflict of interest}

The authors declare no conflict of interests.

\section{Author contributions}

YLL, YSW and YL conceived and designed the study; YLL, HTH, RW and CHL conducted the experiments; YLL, HTH, YLZ and CFW analyzed the data; YLL, $\mathrm{CHL}$ and HTH wrote the manuscript. All authors read and approved the final version.

\section{References}

Alarcon-Segovia D, Alarcon-Riquelme ME, Cardiel MH, Caeiro F, Massardo L, Villa AR and Pons-Estel BA (2005) Familial aggregation of systemic lupus erythematosus, rheumatoid arthritis, and other autoimmune diseases in 1,177 lupus patients from the GLADEL cohort. Arthritis Rheumatism 52:1138-1147.

Aringer M, Dorner T, Leuchten N and Johnson SR (2016) Toward new criteria for systemic lupus erythematosus - a standpoint. Lupus 25:805-811.

Bechmann T, Madsen JS, Brandslund I, Lund ED, Ormstrup T, Jakobsen EH, Jylling AM, Steffensen KD and Jakobsen A (2013) Predicting brain metastases of breast cancer based on serum S100B and serum HER2. Oncol Lett 6:1265-1270.

Bianchi R, Giambanco I and Donato R (2010) S100B/RAGEdependent activation of microglia via NF-kappaB and AP-1 Co-regulation of COX-2 expression by S100B, IL-1beta and TNF-alpha. Neurobiol Aging 31:665-677.

Bianchi R, Kastrisianaki E, Giambanco I and Donato R (2011) $\mathrm{S} 100 \mathrm{~B}$ protein stimulates microglia migration via RAGEdependent up-regulation of chemokine expression and release. J Biol Chem 286:7214-7226.

Cao T, Zhang L, Yao LL, Zheng F, Wang L, Yang JY, Guo LY, Li XY, Yan YW, Pan YM et al. (2017) S100B promotes injury-induced vascular remodeling through modulating smooth muscle phenotype. Biochim Biophys Acta MOl Basis Dis 1863:2772-2783.

Dang X, Guan L, Hu W, Du G and Li J (2014) S100B ranks as a new marker of multiple traumas in patients and may accelerate its development by regulating endothelial cell dysfunction. Int J Clin Exp Pathol 7:3818-3826.

Dix A, Czakai K, Springer J, Fliesser M, Bonin M, Guthke R, Schmitt AL, Einsele H, Linde J and Loffler J (2016) Genome-wide expression profiling reveals $\mathrm{S} 100 \mathrm{~B}$ as biomarker for invasive Aspergillosis. Front Microbiol 7:320.

Donato R, Sorci G, Riuzzi F, Arcuri C, Bianchi R, Brozzi F, Tubaro C and Giambanco I (2009) S100B's double life: Intracellular regulator and extracellular signal. Biochim Biophys Acta 1793:1008-1022.

Donato R, Cannon BR, Sorci G, Riuzzi F, Hsu K, Weber DJ and Geczy CL (2013) Functions of S100 proteins. Curr Mol Med 13:24-57.

Egger G, Roetzer KM, Noor A, Lionel AC, Mahmood H, Schwarzbraun T, Boright O, Mikhailov A, Marshall CR, Windpassinger C et al. (2014) Identification of risk genes for autism spectrum disorder through copy number variation analysis in Austrian families. Neurogenetics 15:117-127.

Fragoso-Loyo H, Cabiedes J, Atisha-Fregoso Y, Llorente L and Sanchez-Guerrero J (2010) Utility of serum S100B protein for identification of central nervous system involvement in systemic lupus erythematosus. J Rheumatol 37:2280-2285.

Gomez-Tourino I, Simon-Vazquez R, Alonso-Lorenzo J, Arif S, Calvino-Sampedro C, Gonzalez-Fernandez A, Pena-Gonzalez E, Rodriguez J, Vinuela-Roldan J, Verdaguer J et al. (2015) Characterization of the autoimmune response against the nerve tissue S100beta in patients with type 1 diabetes. Clin Exp Immunol 180:207-217.

Guo Y, Yang H, Deng X, Song Z, Yang Z, Xiong W, Yuan L, Xu H, Deng S and Deng H (2013) Genetic analysis of the S100B gene in Chinese patients with Parkinson disease. Neurosci Lett 555:134-136.

Hochberg MC (1997) Updating the American College of Rheumatology revised criteria for the classification of systemic lupus erythematosus. Arthritis Rheumatism 40:1725.

Hofmann MA, Drury S, Fu C, Qu W, Taguchi A, Lu Y, Avila C, Kambham N, Bierhaus A, Nawroth P et al. (1999) RAGE mediates a novel proinflammatory axis: A central cell surface receptor for S100/calgranulin polypeptides. Cell 97:889-901.

Hohoff C, Ponath G, Freitag CM, Kastner F, Krakowitzky P, Domschke K, Koelkebeck K, Kipp F, von Eiff C, Deckert J and Rothermundt M (2010) Risk variants in the S100B gene predict elevated S100B serum concentrations in healthy individuals. Am J Med Genet B Neuropsychiatr Genet 153b:291-297.

Holloway L, Humphrey L, Heron L, Pilling C, Kitchen H, Hojbjerre L, Strandberg-Larsen M and Hansen BB (2014) Patient-reported outcome measures for systemic lupus erythematosus clinical trials: A review of content validity, face validity and psychometric performance. Health quality Life Outcomes 12:116.

Hwang CC, Chai HT, Chen HW, Tsai HL, Lu CY, Yu FJ, Huang MY and Wang JY (2011) S100B protein expressions as an independent predictor of early relapse in UICC stages II and III colon cancer patients after curative resection. Ann Surg Oncol 18:139-145. 
Lapa AT, Postal M, Sinicato NA, Bellini BS, Fernandes PT, Marini R and Appenzeller S (2017) S100beta is associated with cognitive impairment in childhood-onset systemic lupus erythematosus patients. Lupus 26:478-483.

Li J, Shan RB, Liu RH, Xu YJ, Qu NY, Pan GM, Zhang N, Yang N, Chen ZZ, Zhang WX and Li ZP (2017) Association between S100B gene polymorphisms and hand, foot and mouth disease caused by enterovirus 71 infection. Zhongguo Dang Dai Er Ke Za Zhi. 19:904-907.

Li R, Sun J, Ren LM, Wang HY, Liu WH, Zhang XW, Chen S, Mu R, He J, Zhao Y, et al. (2012) Epidemiology of eight common rheumatic diseases in China: A large-scale crosssectional survey in Beijing. Rheumatology 51:721-729.

Liu J, Shi Y, Tang J, Guo T, Li X, Yang Y, Chen Q, Zhao X, He G, Feng $\mathrm{G}$ et al. (2005) SNPs and haplotypes in the S100B gene reveal association with schizophrenia. Biochem Biophys Res Commun 328:335-341.

Matsson H, Huss M, Persson H, Einarsdottir E, Tiraboschi E, Nopola-Hemmi J, Schumacher J, Neuhoff N, Warnke A, Lyytinen $\mathrm{H}$ et al. (2015) Polymorphisms in DCDC2 and S100B associate with developmental dyslexia. J Hum Genet 60:399-401.

Miki Y, Gion Y, Mukae Y, Hayashi A, Sato H, Yoshino T and Takahashi K (2013) Morphologic, flow cytometric, functional, and molecular analyses of S100B positive lymphocytes, unique cytotoxic lymphocytes containing S100B protein. Eur J Haematol 90:99-110.

Niven J, Hoare J, McGowan D, Devarajan G, Itohara S, Gannage M, Teismann P and Crane I (2015) S100B Up-regulates macrophage production of IL1beta and CCL22 and influences severity of retinal inflammation. PLoS One 10:e 0132688 .

Roche S, Cassidy F, Zhao C, Badger J, Claffey E, Mooney L, Delaney C, Dobrin S and McKeon P (2007) Candidate gene analysis of 21q22: support for $\mathrm{S} 100 \mathrm{~B}$ as a susceptibility gene for bipolar affective disorder with psychosis. Am J Med Genet B Neuropsychiatr Genet 144B:1094-1096.

Shao Y, Shao X, He J, Cai Y, Zhao J, Chen F, Tao H, Yin Z, Tan $\mathrm{X}, \mathrm{He} \mathrm{Y}$ et al. (2017) The promoter polymorphisms of receptor for advanced glycation end products were associated with the susceptibility and progression of sepsis. Clin Genet 91:564-575.

Shi X, Qian T, Li M, Chen F, Chen Y and Hao F (2015) Aberrant low expression of A20 in Tumor Necrosis Factor-alphastimulated SLE monocytes mediates sustained NF-kappaB inflammatory response. Immunol Invest 44:497-508.

Shi YY and He L (2005) SHEsis, a powerful software platform for analyses of linkage disequilibrium, haplotype construction, and genetic association at polymorphism loci. Cell Res 15:97-98

Sun KH, Yu CL, Tang SJ and Sun GH (2000) Monoclonal antidouble-stranded DNA autoantibody stimulates the expression and release of IL-1beta, IL-6, IL-8, IL-10 and TNFalpha from normal human mononuclear cells involving in the lupus pathogenesis. Immunology 99:352-360.

Sun T, Gao Y, Tan W, Ma S, Shi Y, Yao J, Guo Y, Yang M, Zhang $\mathrm{X}$, Zhang Q et al. (2007) A six-nucleotide insertion-deletion polymorphism in the CASP8 promoter is associated with susceptibility to multiple cancers. Nat Genet 39:605-613.
Tiffin N, Adeyemo A and Okpechi I (2013) A diverse array of genetic factors contribute to the pathogenesis of systemic lupus erythematosus. Orphanet J Rare Dis 8:2.

Ulff-Moller CJ, Simonsen J, Kyvik KO, Jacobsen S and Frisch M (2017) Family history of systemic lupus erythematosus and risk of autoimmune disease: Nationwide Cohort Study in Denmark 1977-2013. Rheumatology 56:957-964.

Uspenskaya YA, Komleva YK, Pozhilenkova EA, Salmin VV, Lopatina OL, Fursov AA, Lavrentiev PV, Belova OA and Salmina AB (2015) Ligands of RAGE-proteins: Role in intercellular communication and pathogenesis of inflammation. Vestnik Rossiiskoi Akad Meditsin Nauk 2015:694703.

Wada Y, Hasegawa H, Saeki T, Ito S, Kuroda T, Nakano M and Narita I (2017) Long-term prognosis and factors associated with damage accrual in Japanese patients with systemic lupus erythematosus. Clin Exp Nephrol 22:597-692.

Wang JB, Li H, Wang LL, Liang HD, Zhao L and Dong J (2015) Role of IL-1beta, IL-6, IL-8 and IFN-gamma in pathogenesis of central nervous system neuropsychiatric systemic lupus erythematous. Int J Clin Exp Med 8:16658-16663.

Wang XK, Zhang HL, Meng FH, Chang M, Wang YZ, Jin T, Mix E and Zhu J (2013) Elevated levels of S100B, tau and pNFH in cerebrospinal fluid are correlated with subtypes of Guillain-Barre syndrome. Neurol Sci 34:655-661.

Xiao L, Sun W, Lan W, Xiong Y, Duan Z, Zhang Z, Fan W, Xu L, Xie X, Ma N et al. (2014) Correlation between cerebral microbleeds and S100B/RAGE in acute lacunar stroke patients. J Neurol Sci 340:208-212.

Yang K, Hu YQ, Xie GR, Mao FQ and Su LY (2008) No association of the rs9722 C $>\mathrm{T}$ in the $\mathrm{S} 100 \mathrm{~B}$ gene and susceptibility to major depression in a Chinese population. Genet Testing 12:487-489

Yang XY, Lin J, Lu XY and Zhao XY (2008) Expression of S100B protein levels in serum and cerebrospinal fluid with different forms of neuropsychiatric systemic lupus erythematosus. Clin Rheumatol 27:353-357.

Yardan T, Erenler AK, Baydin A, Aydin K and Cokluk C (2011) Usefulness of $\mathrm{S} 100 \mathrm{~B}$ protein in neurological disorders. JPMA J Pakistan Med Assoc 61:276-281.

Ye L, Ji L, Wen Z, Zhou Y, Hu D, Li Y, Yu T, Chen B, Zhang J, Ding L et al. (2014) IL-37 inhibits the production of inflammatory cytokines in peripheral blood mononuclear cells of patients with systemic lupus erythematosus: Its correlation with disease activity. J Transl Med 12:69.

Zhai J, Zhang Q, Cheng L, Chen M, Wang K, Liu Y, Deng X, Chen X, Shen Q, Xu Z et al. (2011) Risk variants in the S100B gene, associated with elevated S100B levels, are also associated with visuospatial disability of schizophrenia. Behav Brain Res 217:363-368.

Zhi-Chun L, Qiao-Ling Z, Zhi-Qin L, Xiao-Zhao L, Xiao-Xia Z and Rong T (2012) Tumor necrosis factor-like weak inducer of apoptosis (TWEAK) mediates p38 mitogen-activated protein kinase activation and signal transduction in peripheral blood mononuclear cells from patients with lupus nephritis. Inflammation 35:935-943.

Associate Editor: Regina C. Mingroni-Netto

License information: This is an open-access article distributed under the terms of the Creative Commons Attribution License (type CC-BY), which permits unrestricted use, distribution and reproduction in any medium, provided the original article is properly cited. 